\title{
Anti-tumor necrosis factor therapy in children with refractory Takayasu arteritis: report of five cases
}

\author{
YO Kostina*, GA Lyskina, GM Rabieva, EV Uspenskaya \\ From 18th Pediatric Rheumatology European Society (PReS) Congress \\ Bruges, Belgium. 14-18 September 2011
}

\section{Background}

Takayasu arteritis (TA) is a well known rare form of large vessel vasculitis characterized by granulematous inflammation. There are no controlled studies of medical treatment of children with TA.

\section{Aim}

Tumor necrosis factor (TNF) is the most important in the formation of granulomas. The granulomatous nature of the histopathologic lesion in TA led us to consider an evaluation of the therapeutic benefits of anti-TNF therapy in patients with refractory TA.

In our study five children (5 girls) aged from 10 to 17 years with widespread inflammation in the aorta and its main branches were treated with infliximab during 6 months. The mean duration of the disease was 4.5 years. All patients received oral steroids and methotrexate or cyclophosphamide. The cause for anti-TNF treatment was standart therapy tolerance and uncontrolled arterial hypertension. Patients were tested for tuderculosis by skin test and chest roentgenography. Also we excluded active systemic infections, neutropenia, thrombocytopenia and liver dysfunction.

\section{Methods}

The efficacy of infliximab therapy was evaluated by inflammation markers - erythrocyte sedimentation rate (ESR), C-reactive protein (CRP), fibrinogen, - clinical symptoms and results of doppler ultrasound.

\footnotetext{
* Correspondence: julialonkos@mail.ru

I.M. Sechenov First Moscow State Medical University, Department of childhood diseases, Moscow, Russia
}

(c) 2011 Kostina et al; licensee BioMed Central Ltd. This is an open access article distributed under the terms of the Creative Commons Attribution License (http://creativecommons.org/licenses/by/2.0), which permits unrestricted use, distribution, and reproduction in any medium, provided the original work is properly cited.
Cite this article as: Kostina et al:: Anti-tumor necrosis factor therapy in children with refractory Takayasu arteritis: report of five cases. Pediatric Rheumatology 2011 9(Suppl 1):P82.

Submit your next manuscript to BioMed Central and take full advantage of:

- Convenient online submission

- Thorough peer review

- No space constraints or color figure charges

- Immediate publication on acceptance

- Inclusion in PubMed, CAS, Scopus and Google Scholar

- Research which is freely available for redistribution 